\title{
Significant effect of accidental pollinations on the progeny of low setting Prunus interspecific crosses
}

\author{
Arancha Arbeloa $^{1 *}$, M.E. Daorden ${ }^{1,2}$, E. García ${ }^{1}$, A. Wünsch ${ }^{3}$, J.I. Hormaza ${ }^{4}$ \& J.A. \\ Marín $^{1}$ \\ ${ }^{1}$ Estación Experimental de Aula Dei (CSIC). Apartado 202. 50080 Zaragoza, Spain; \\ ${ }^{2}$ Permanent address: EEA San Pedro-INTA. C.C. 43. 2930 Buenos Aires, Argentina; \\ ${ }^{3}$ CITA-DGA. Campus Aula Dei. Apdo 727, 50080 Zaragoza, Spain; ${ }^{4}$ Estación \\ Experimental La Mayora (CSIC). 29750 Algarrobo-Costa, Málaga, Spain; (*author for \\ correspondence: e-mail: arbeloa@eead.csic.es )
}

Key words: hybrid identification, interspecific hybridization, microsatellites, Prunus breeding, SSRs.

\section{Summary}

The incidence of fortuitous pollination on interspecific hybridizations of the plum rootstock Myrobalan with the apricot cultivars 'Moniquí' and 'Moniquí Borde' was assessed in this work. Progeny was originated through hand pollination of emasculated flowers of three Myrobalan clones, without bagging, in 1998 and 1999. Fruit set was low and variable among years (1.8-8.0\%), but higher than the level of accidental pollination measured with emasculated and non-pollinated flowers (1.2\%). Molecular characterization of the progeny was performed with three SSR markers showing that only $28 \%$ of the seedlings, obtained by in vitro germination and culture of immature embryos, were hybrids. This represents a lower percentage than expected, and is explained here by the low viability of hybrid embryos and seedlings. The use of molecular markers is discussed in terms of a convenient method for an early identification of putative hybrids in breeding programs with low setting crosses, where the proportion of non-hybrids is magnified.

\section{Introduction}

Interspecific crosses to transfer interesting traits among species are common tools in fruit tree breeding programs (Layne \& Sherman, 1986). However, genetic barriers to hybridization are often an obstacle for the obtention of interspecific hybrids (Perez \& Moore, 1985) resulting, in most cases, in low ovule fertilization, high embryo abortion, or high fruit abscission rates. Embryo abortion and fruit abscission are frequently the result of postzygotic incompatibility barriers (Stebbins, 1958) that make seeds unviable. However, the development of embryo rescue techniques applied after fertilization has facilitated hybrid obtention (Ramming, 1990), allowing embryo development and in vitro germination of unviable seeds, becoming a useful tool in Prunus breeding programs (Arbeloa et al., 2000, 2003).

Hybridization is commonly performed by hand pollination of emasculated flowers both to avoid self-pollination and to make flowers unattractive to pollinator insects (Free, 1964), thus increasing the chances of ovule fertilization by the desired pollen. Bagging emasculated flowers to avoid unwanted pollination is a safe practice although it is labour demanding and, consequently, it is often omitted in situations where the risk of accidental pollination is considered as reasonably low (van der Zeet et 
al., 1977; Moore \& Janick, 1983; Sedgley \& Griffin, 1989). Accidental pollinations of emasculated flowers have been reported at low levels (2-5\%) in apricot (Viti et al., 1997) or Japanese quince (Kaufmane \& Rumpunen, 2002) and as negligible in mango or poplar (Singh et al., 1980; Houston \& Joehlin, 1989). However, this situation may be more unfavourable in circumstances where final fruit setting is very low such as interspecific crosses.

Until the development of molecular marker techniques, the assessment of fertilization with unwanted pollen could only be made with morphological traits, but this is only viable when the contamination occurs with pollen from genotypes very different from those used in the controlled pollinations. Moreover, in cases where morphological traits could discriminate among wanted and unwanted crosses, phenotypic traits are usually expressed late in development and they are subject to environmental influences. Consequently, molecular marker techniques are an important tool to speed and increase the accuracy of paternity assessment in controlled crosses. Several molecular marker techniques have been applied for paternity analysis in fruit tree species (Wünsch \& Hormaza, 2002). However, microsatellites or simple sequence repeats (SSRs) have become the markers of choice for fingerprinting and paternity analyses in most plant species (Gupta \& Varshney, 2000) due to their high polymorphism, codominancy and reproducibility. Over 100 microsatellite markers have been so far reported in peach (Cipriani et al., 1999; Testolin et al., 2000; Sosinski et al., 2000; Aranzana et al., 2002, 2003; Dirlewanger et al., 2002) and many of them are transferable to other related species (Hormaza, 2002; Wünsch \& Hormaza, 2002).

In this work, the incidence of fortuitous pollinations on interspecific hybridizations of Myrobalan (Prunus cerasifera Ehrh.) x apricot (Prunus armeniaca L.) crosses was assessed. SSR markers were used in order to know the extent of fortuitous pollinations on these crosses to define advisable practices that can also be useful for other interspecific crosses, not only in Prunus, but also in other fruit tree genera.

\section{Materials and methods}

\section{Interspecific hybridization}

Flowers of three different clones (Mb1, Mb2 and Mb3) of Myrobalan (Prunus cerasifera Ehrh) were pollinated with pollen of the apricot (Prunus armeniaca L.) cultivars 'Moniquí' (M) and 'Moniquí Borde' (MB) two consecutive years. The trees are maintained at the orchard collection of the Experimental Research Station of Aula Dei, CSIC (Zaragoza, Spain). Flowering took place at the end of February. Myrobalan flowers at balloon stage were emasculated 1 day before anthesis to prevent pollination (Free, 1964) and flowers in earlier or later stages were eliminated from marked branches. Pistils were hand-pollinated the following day with pollen from the apricot cultivars. A total of 3969 flowers in 1998 and 5382 flowers in 1999 were hand pollinated in the three Myrobalan trees. Six different crosses were performed: Mb1xM, Mb2xM, Mb2xMB and Mb3xM in 1998, and Mb1xM, Mb1xMB, Mb2xM, Mb2xMB, Mb3xM and Mb3xMB in 1999 (Table 1, 2). Since emasculated flowers were unattractive to insects (Free, 1964), no bagging was applied to pollinated branches.

\section{Embryo rescue and in vitro culture}


Immature Myrobalan fruits from the hand-pollinated flowers were harvested 12 weeks after pollination. Immature embryos were extracted from fruits under aseptic conditions and cultured, for germination, in Chée \& Pool (1987) medium without growth regulators (Daorden et al., 2002, 2004). After germination, shoot apices were excised from the seedlings and multiplied in a modified MS (Murashige \& Skoog, 1962) medium adding $1.19 \mu \mathrm{M}$ thiamine- $\mathrm{HCl}, 5 \mu \mathrm{M}$ Benzylaminopurine and $0.5 \mu \mathrm{M}$ Indolbutiric acid (IBA). Germination and survival rates were recorded for each treatment. Shoots were later rooted in vitro in half MS medium with $5 \mu \mathrm{M}$ IBA (Arbeloa et al., 2003). Micropropagated plants were acclimatized (Marín, 2003) and finally transplanted to orchard conditions.

\section{Fruit set assessment}

In order to assess the level of accidental pollinations of the three Myrobalan clones, fruit set was determined in 1) emasculated non-pollinated flowers, 2) emasculated and selfpollinated flowers and 3) non-emasculated open-pollinated flowers in each Myrobalan clone (Mb1, Mb2 and Mb3). A set of 416, 558 and 488 emasculated flowers of Mb1, Mb2 and Mb3 respectively was non-pollinated and another set of 478, 566 and 471 flowers, respectively, were self-pollinated, and finally, a set of 509, 463 and 688 flowers, respectively, was controlled for fruit set of open-pollinated branches. Flowers were counted weekly from anthesis until harvest. Fruit set was determined for each treatment and clone.

\section{Progeny characterization}

The parental genotype clones, three Myrobalan and two apricots, as well as the putative hybrids, 35 plants grown in the greenhouse and 184 seedlings from in vitro growing shoots, were analysed with SSRs to identify the hybrid status of the progeny. Progeny of every cross combination was studied and the number of analysed seedlings depended on the material available at the moment of the analysis (Table 1, 2). Genomic DNA from all the plant material was isolated according to Hormaza (2002).

For the SSR analysis, the parental genotypes were initially screened with eight SSR loci previously developed in peach by Cipriani et al. (1999) and Sosinski et al. (2000), that have already been shown to be conserved in apricot (Hormaza, 2002) and Myrobalan (Serrano et al., 2002) genotypes: pchgms2, UDP96-003, UDP96-005, UDP96-008, UDP96-018, UDP98-405, UDP98-406 and UDP98-409. Three SSR loci (pchgms2, UDP96-003 and UDP96-008), polymorphic among the parental genotypes, were selected to confirm the hybrid origin of progeny. PCR reactions for SSR amplifications were carried out in $20 \mu \mathrm{L}$ volumes containing $20 \mathrm{mM}$ Tris- $\mathrm{HCl}, \mathrm{pH}$ 8.4, $50 \mathrm{mM} \mathrm{KCl}, 4$ $\mathrm{mM} \mathrm{MgCl} 2,0.1 \mathrm{mM}$ each dNTP, $0.2 \mu \mathrm{M}$ each primer, $40 \mathrm{ng}$ genomic DNA and 0.45 units Taq polymerase (Invitrogen, Carlsbad, CA), using the following temperature profile: an initial step of 2 minutes at $94{ }^{\circ} \mathrm{C}, 35$ cycles of 45 seconds at $94{ }^{\circ} \mathrm{C}, 45$ seconds at $57{ }^{\circ} \mathrm{C}$ and 1 minute at $72{ }^{\circ} \mathrm{C}$, and a final step of 5 minutes at $72{ }^{\circ} \mathrm{C}$. Microsatellite PCR products were separated by electrophoresis using 3\% Metaphor (FMC Bioproducts, Rockland, ME) agarose gels in $1 \mathrm{X}$ TBE buffer at $5 \mathrm{~V} / \mathrm{cm}$, stained with ethidium bromide and visualised under UV light. Band scoring was carried out using a standard 10 bp DNA ladder (Invitrogen). Assuming Mendelian inheritance of the SSR loci, each of the progeny genotypes analysed was considered to be hybrid when one of the two SSR alleles amplified with each loci was the same as one of the two 
alleles in the maternal genotype and the other was the same as one of the SSR alleles found in the paternal genotype (Figure 1).

\section{Results}

Table 1

Table 2

In 1998, from a total of 3969 flowers pollinated either with Moniquí or Moniquí Borde pollen, 71 fruits (1.8\% fruit set) were obtained. From these fruits, 67 immature embryos were isolated and placed to germinate in vitro (Table 1). An average of $78 \%$ of the embryos developed into seedlings and were later maintained in vitro through subsequent cultures. During the post-germination growth and multiplication phases, $20 \%$ of the genotypes were lost after one year of in vitro multiplication. Some of them died soon after germination, once seedlings were transplanted to the culture room, and the rest died along the multiplication period (Table 1)

In 1999, from a total 5382 flowers pollinated either with Moniquí or Moniquí Borde pollen, 431 fruits (8.0 \% fruit set) were obtained. Immature embryos were isolated and placed in vitro onto culture medium to germinate. Germination took place in an average of $85 \%$ of the embryos. During post-germination growth and multiplication phases $20 \%$ of the genotypes were lost in a similar way than in 1998 (Table 2).

The assessment of the level of accidental pollinations was performed on emasculated flowers. Average fruit set of the three maternal clones in non-pollinated flowers was $1.1 \%$, similar to that of self-pollinated flowers $(0.9 \%)$, whereas it rose up to $11.5 \%$ in open-pollination conditions (Table 3).

Tahle 3

\section{Progeny characterization}

The SSR loci pchgms2, UDP96-003 and UDP96-008, polymorphic for the Myrobalan and apricot clones, were used to confirm the hybrid origin of the progenies (Table 4). From the 219 progeny genotypes evaluated (Table 1, 2), 61 showed hybrid origin and 158 did not (Figure 1). The percentage of hybrids confirmed by microsatellites, among the progeny in both years was 37.1\% in 1998 and 26\% in 1999.

Table 4

Figure 1

\section{Discussion}

In this work we have studied the impact of accidental pollinations in interspecific crosses of three Myrobalan plum clones hand-pollinated with pollen from two apricot cultivars, Moniquí and Moniquí Borde. We have found a high proportion of non-hybrid plants, derived from these fortuitous pollinations. The low fruit settings obtained in these controlled pollinations is due to the incongruity between the applied apricot pollen and Myrobalan (Perez \& Moore, 1985). As a consequence, fertilization of Myrobalan ovules by accidental pollen that manage to reach the stigmas will be favoured against the apricot applied pollen.

Lack of protection of flowers through bagging pollinated branches is likely to increase the chance of accidental pollinations. However, bagging of flowers does not guarantee the lack of undesired pollinations, since accidental pollinations have been found even in cases where flowers were bagged (de la Rosa et al., 2004; Neal \& Anderson, 2004). Many breeding programs avoid covering the flowers (van der Zeet et al., 1977), since breeders consider that a small level of contamination is an acceptable 
price to pay for cost and time saving (Sedgley \& Griffin, 1989; Moore \& Janick, 1983). In our case, accidental pollination are very low considering the total pollinated flowers (around 1\% of the total number of hand-pollinated flowers): 22 non-hybrid seedlings from to 3696 pollinated flowers in 1998 and 158 non-hybrid seedlings from 5382 pollinated flowers in 1999. This suggests that fortuitous pollinations could be a rare phenomenon that goes usually unnoticed in most fruit breeding programs.

However, this small percentage of non-hybrid seeds resulted magnified later due to the advantages of non-hybrid versus hybrid embryos along the process of setting, seed development, seed germination and seedling growth. First, interspecific hybrid seeds are difficult to obtain since reproductive isolation mechanisms may act at the preor post-fertilization levels by arresting embryo and/or endosperm development (Bushell et al., 2003). On the other hand, non-hybrid seeds do not suffer incompatibility barriers compared to hybrid seeds, thus most of the accidental pollinated flowers yielded viable seeds. Second, in vitro germination and multiplication are also advantageous for nonhybrid seeds. On the one hand, germination success is highly dependent on seed size (Ramming, 1990; Burgos \& Ledbetter, 1993) and, thus, higher germination rates are obtained with larger seeds. Non-hybrid seeds are regularly larger than hybrid seeds since they do not undergo developmental arrest due to post-zygotic incompatibility barriers (Daorden et al., 2002, 2004). A significant percentage of embryos were smaller than $8 \mathrm{~mm}$ at harvest, what is considered as abortive seeds (Arbeloa et al., 2000). In optimal in vitro germination conditions, germination rate was $95.6 \%$ for embryos larger than $8 \mathrm{~mm}$ (non-abortive seeds) and 60\% for the embryos smaller than $8 \mathrm{~mm}$ (abortive seeds) (Daorden at al., 2002; Arbeloa et al., 2003; Daorden et al. 2004). Moreover, whereas in vitro multiplication of Myrobalan is easy and rapid (Hammerschlag, 1982) apricot is considered a recalcitrant species (Marino et al., 1993). Consequently, due to their apricot genetic inheritance, hybrid seedlings could die along the in vitro multiplication phase in a higher proportion than non-hybrid seedlings. We have shown that $20 \%$ of the seedlings are lost after one year of cultivation in vitro, and most of them are presumed to be hybrid ones. As a result, in this work, low percentages of hybrid plants were identified following the characterization process. Due to the magnification of the rates of non-hybrid seedling obtention along the process, accidental pollinations in this type of crosses should be carefully traced.

The pollen origin of accidental pollinations may be diverse and, among different sources, self-pollination is an acceptable possibility. However Myrobalan has been described as a total or partial self-incompatible species (Layne \& Sherman, 1986; Esmenjaud et al., 1996; Lecouls et al., 1999); this is in agreement with the low fruit set rate obtained in self-pollinated flowers. In emasculated but non-pollinated flowers accidental pollinations also occurred since an average of $1.1 \%$ of the flowers set fruit, a value close to that obtained in self-pollinated flowers $(0.9 \%)$ indicating that a similar accidental process could happen. Consequently, it is likely that pollen for accidental pollinations in both cases arrives by wind or gravity from adjacent trees as it has been shown in other species (Visser \& Vergaegh, 1980).

We have found that most of the progeny from interspecific crosses appeared to be non-hybrid seedlings. Consequently, accidental pollinations should be carefully avoided. One option is to bag the flowers before and after the application of the desired pollen; however, this technique is costly and time consuming. Another alternative is to carry out early hybrid identification in breeding programs with low setting crosses. Thus, microsatellites applied to paternity identification have revealed here as a very useful tool as in other species (de la Rosa et al., 2004). A quick test on tissues of the cotyledon after embryo isolation (Hormaza, 1999) would allow screening for hybrids in 
a very early stage of the selection process, since embryos can germinate in vitro even without cotyledons (Arbeloa et al., 2000). This would allow the elimination of nonhybrid seeds at early stages avoiding tedious techniques as bagging or morphological hybrid identification.

\section{Acknowledgements}

We gratefully acknowledge T. Bespín and E. Sánchez for technical assistance. This work was supported by projects CONSID - DGA: P012/2001, and CICYT: AGL2001-2414-C04-01 and AGL2002-03231-AGR-FOR. MED was supported by a fellowship from INTA, Argentina.

\section{References}

Aranzana, M.J., J. García-Mas, J. Carbó, \& P. Arus. 2002. Development and variability analysis of microsatellite markers in peach. Plant Breed 121: 87--92.

Aranzana, M.J., A. Pineda, P. Cosson, E. Dirlewanger, J. Ascasibar, G. Cipriani, C.D. Ryder, R. Testolin, A. Abbott, G.J. King, A.F. Iezzoni \& P. Arus. 2003. A set of simple sequence repeat (SSR) markers covering the Prunus genome. Theor Appl Genet 106(5): 819--825.

Arbeloa, A., E. García, M.E. Daorden, P. Andreu \& J.A. Marín. 2000. Germinación in vitro de semillas inmaduras de mirobolán (Prunus cerasifera Ehrh.). ITEA 21 (Ext.): 59--61.

Arbeloa, A., M.E. Daorden, E. García \& J.A Marín. 2003. Successful establishment of in vitro culture of Prunus cerasifera hybrids by embryo culture of immature fruits. Acta Horticulturae 616: 375--378.

Burgos, L. \& C.A. Ledbetter. 1993. Improved efficiency in apricot breeding: Effects of embryo development and nutrient media on in vitro germination and seedling establishment. Plant Cell Tiss Org Cult 35: 217--222.

Bushell, C., M. Spielman \& R.J. Scott. 2003. The basis of natural and artificial postzygotic hybridization barriers in Arabidopsis Species. Plant Cell 15: 1430--1442.

Chée, R. \& R.M. Pool. 1987. Improved inorganic media constituents for in vitro shoot multiplication of Vitis. Sci. Hort 32: 85--95.

Cipriani, G., G. Lot, W.G. Huang, M.T. Marrazzo, E. Peterlunger \& R. Testolin. 1999. AC/GR and AG/CT microsatellite repeats in peach [Prunus persica (L) Batsch]: isolation, characterisation and cross-species amplification in Prunus. Theor Appl Genet 99: 65--72.

Daorden, M.E., J.A. Marín \& A. Arbeloa. 2002. Germinación in vitro de embriones inmaduros a distintas temperaturas de estratificación. ITEA 98V: 71--80 . 
Daorden, M.E., J.A. Marín \& A. Arbeloa. 2004. Stratification temperature affects in vitro germination of immature Prunus embryos. Acta Horticulturae 658(1): 135--140.

Dirlewanger, E., P. Cosson, M. Tavaud, M.J. Aranzana, C. Poizat, A. Zanetto, P. Arus \& F. Laignet. 2002. Development of microsatellite markers in peach [Prunus persica (L) Bastch] and their use in genetic diversity analysis in peach and sweet cherry (Prunus avium L.). Theor Appl Genet 105(1): 127--138.

Esmenjaud, D., J.C. Minot, R. Voisin, A. Bonet \& G. Salesses. 1996. Inheritance of resistance to the root-knot nematode Meloidogyne arenaria in Myrobalan plum. Theor Appl Genet 92: 873--879.

Free, J.B. 1964. Comparison of the importance of insect and wind pollination of apple trees. Nature (Lond) 201, 726--727.

Gupta, P.K. \& R.K. Varshney. 2000. The development and use of microsatellite markers for genetic analysis and plant breeding with emphasis on bread wheat. Euphytica 113: 163--185.

Hammerschlag, F. 1982. Factors influencing in vitro multiplication and rooting of the plum rootstock Myrobalan (Prunus cerasifera Ehrh.) J Amer Soc Hort Sci 107(1): 44-47

Hormaza, J.I. 1999. Early selection in cherry combining RAPDs with embryo culture. Sci Hort 79: 121--126

Hormaza, J.I. 2002. Molecular characterization and similarity relationships among apricot (Prunus armeniaca L.) genotypes using simple sequence repeats. Theor Appl Genet 104: 321--328.

Houston , D.B. \& K.A. Joehlin. 1989. Are pollination bags needed for controlled pollination programs with yellow-poplar? Silvae Genet 38(3/4): 137--140

Kaufmane, E. \& K. Rumpunen. 2002. Pollination, pollen tube growth and fertilization in Chaenomeles japonica (Japanese quince). Sci Hort 94(3-4): 257--271.

Layne R.E.C. \& W.B. Sherman. 1986. Interspecific hybridisation of Prunus. HortScience 21 (1): 48--51.

Lecouls, A.C., M.J. Rubio-Cabetas, J.C. Minot, R. Voisin, A. Bonet, G. Salesses, E. Dirlewanger \& D. Esmenjaud. 1999. RAPD and SCAR markers linked to the Ma1 rootknot nematode resistance gene in Myrobalan plum (Prunus cerasifera Ehrh.) Theor Appl Genet 99(1-2): 328--335.

Marín JA. 2003. High survival rates during acclimatization of micropropagated fruit tree rootstocks by increasing exposures to low relative humidity. Acta Horticulturae 616: 139--142 
Marino, G., G. Bertazza, E. Magnanini \& A.D. Altan. 1993. Comparative effects of sorbitol and sucrose as main carbon energy sources in micropropagation of apricot. Plant Cell Tiss Org Cult 34: 235--244

Moore, J.N. \& J. Janick. (Eds). 1983. Methods in fruit breeding. Purdue University Press. West Lafayette, Indiana. 464pp.

Murashige T. \& F. Skoog. 1962. A revised medium for rapid growth and bioassays with tobacco tissue cultures. Physiol Plant 15: 473--497.

Neal, P.R. \& G.J. Anderson. 2004. Does the 'Old bag' make a good 'Wind bag'?: Comparison of four fabrics commonly used as exclusion bags in studies of pollination and reproductive biology. Ann Bot 93: 603--607.

Perez, S. \& J.N. Moore. 1985. Prezygotic endogenous barriers to interspecific hybridization in Prunus. J Am Soc Hort Sci 110(2): 267--273.

Ramming, D.W. 1990. The use of embryo culture in fruit breeding. HortScience 25: 393--398.

de la Rosa, R., C.M. James \& K.R. Tobutt. 2004. Using microsatellites for paternity testing in olive progeny. HortScience 39(2): 351--354.

Sedgley, M. \& A.R. Griffin. 1989. Sexual Reproduction of Tree Crops. Academic Press. London

Serrano, B., J. Gómez-Aparisi \& J.I. Hormaza. 2002 Molecular fingerprinting of Prunus rootstocks using SSRs. J Hort Sci Biotech 77 (3): 368--372

Singh, R.N., D.K. Sharma \& P.K Majumder. 1980. An efficient technique of mango hybridization. Sci Hort 12: 299--301.

Sosinski, B., M. Gannavarapu, L.D. Hager, L.E. Beck, G.L. King, C.D. Ryder, S. Rajapakse, W.V. Baird, R.E. Ballard \& A.G. Abbot. 2000. Characterization of microsatellite markers in peach [Prunus persica (L.) Batsch]. Theor Appl Genet 101: 421--428.

Stebbins, G.L. 1958. The inviability, weakness, and sterility of interspecific hybrids. Adv Genet 9: 147--215.

Testolin, R.; T. Marrazzo, G. Cipriani, R. Quarta, I. Verde, M.T. Dettori, M. Pancaldi \& S. Sansavini. 2000. Microsatellite DNA in peach (Prunus persica L. Bastch) and its use in fingerprinting and testing the genetic origin of cultivars. Genome 43: 512--520.

Van der Zwet, T. W.R. Zook \& R.C. Blake. 1977. The USDA pear breeding program. I. Emasculation and pollination. Fruit Var J 31(4): 71--82.

Visser T. \& J.J. Verhaegh. 1980. Pollen and pollination experiments. I. The contribution of stray pollen to the seed set of depetalled, hand-pollinated flowers of apple. Euphytica 29: 379--383. 
Viti, R., P. Monteleone \& R. Guerriero. 1997. Incompatibility in apricot (Prunus armeniaca L.): methodological considerations. J. Hort. Sci. 72 (6): 961--970.

Wünsch, A. \& J.I. Hormaza. 2002. Cultivar identification and genetic fingerprint of temperate fruit tree species using DNA markers. Euphytica 125: 59--67

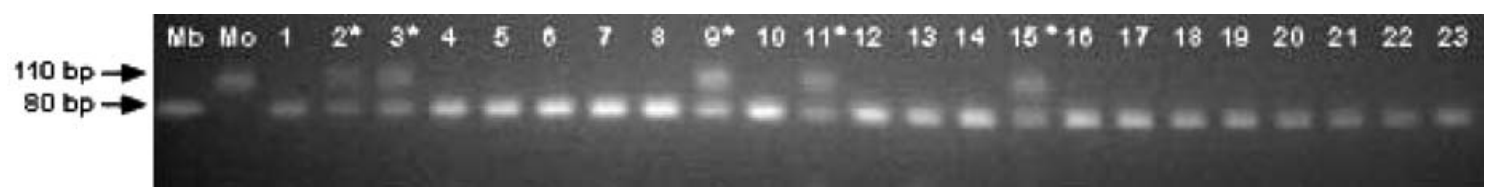

Figure 1. - PCR amplification of the SSR locus UDP96-003 in Myrobalan and Moniquí parental genotypes, and in 23 progeny genotypes. Amplification of one allele of $80 \mathrm{bp}$ in Myrobalan (line Mb), one allele of $110 \mathrm{bp}$ in Moniquí (line Mo), two alleles of 80 and $110 \mathrm{bp}$ in hybrid progenies (lines 1 to 23 marked with *) and a single allele of $80 \mathrm{bp}$ in non hybrid progenies (lines 1 to 23 not marked with *).

Table 1. - Number of pollinated flowers, fruit set, in vitro germination rate, survival of seedlings, and SSR analysed seedlings in 1998

\begin{tabular}{|c|c|c|c|c|c|c|c|}
\hline & $\begin{array}{c}\text { Number of } \\
\text { pollinated } \\
\text { flowers }\end{array}$ & $\begin{array}{c}\text { Number } \\
\text { of fruits }\end{array}$ & $\begin{array}{c}\text { Fruit } \\
\text { set (\%) }\end{array}$ & $\begin{array}{c}\text { Germinated } \\
\text { seeds }\end{array}$ & $\begin{array}{c}\text { Germination } \\
\text { rate (\%) }\end{array}$ & $\begin{array}{c}\text { Growing } \\
\text { seedlings } \\
\text { (1 year } \\
\text { later) }\end{array}$ & $\begin{array}{c}\text { SSR } \\
\text { analysed } \\
\text { seedlings }\end{array}$ \\
\hline Mb1 x M & 1072 & 13 & 1.2 & 10 & 83 & 8 & 8 \\
\hline Mb2 x M & 567 & 26 & 4.6 & 18 & 72 & 15 & 14 \\
\hline Mb2 x MB & 1130 & 19 & 1.7 & 13 & 76 & 13 & 9 \\
\hline Mb3 X M & 1200 & 13 & 1.1 & 8 & 62 & 7 & 4 \\
\hline Total & 3969 & 71 & 1.8 & 49 & 78 & 43 & 35 \\
\hline
\end{tabular}

Table 2. - Number of pollinated flowers, fruit set, in vitro germination rate, survival of seedlings, and SSR analysed seedlings in 1999

\begin{tabular}{|l|c|c|c|c|c|c|c|}
\hline & $\begin{array}{c}\text { Number of } \\
\text { pollinated } \\
\text { flowers }\end{array}$ & $\begin{array}{c}\text { Number } \\
\text { of fruits }\end{array}$ & $\begin{array}{c}\text { Fruit } \\
\text { set (\%) }\end{array}$ & $\begin{array}{c}\text { Germinated } \\
\text { seeds }\end{array}$ & $\begin{array}{c}\text { Germination } \\
\text { rate (\%) }\end{array}$ & $\begin{array}{c}\text { Growing } \\
\text { seedlings } \\
\text { (1 year } \\
\text { later) }\end{array}$ & $\begin{array}{c}\text { SSR } \\
\text { analysed } \\
\text { seedlings }\end{array}$ \\
\hline Mb1 x M & 912 & 40 & 4.4 & 36 & 90 & 30 & 25 \\
\hline Mb1 x MB & 870 & 33 & 3.8 & 30 & 88 & 24 & 19 \\
\hline Mb2 x M & 630 & 21 & 3.3 & 9 & 64 & 3 & 2 \\
\hline Mb2 x MB & 859 & 8 & 0.9 & 5 & 71 & 5 & 2 \\
\hline Mb3 X M & 1202 & 159 & 13.2 & 142 & 88 & 96 & 59 \\
\hline Mb3 x MB & 909 & 170 & 18.7 & 144 & 86 & 132 & 77 \\
\hline Total & 5382 & 431 & 8.0 & 366 & 85 & 290 & 184 \\
\hline
\end{tabular}

Table 3. - Fruit set (\%) in the three Myrobalan clones (Myrobalan 1, 2 and 3) following open-, non- or self-pollination of flowers.

\begin{tabular}{|l|c|c|c|c|}
\hline & Myrobalan 1 & Myrobalan 2 & Myrobalan 3 & Mean \\
\hline Open-pollination & 4.4 & 22.2 & 10.4 & 11.5 \\
\hline
\end{tabular}




\begin{tabular}{|l|l|l|l|l|}
\hline Non-pollination & 0.5 & 0.7 & 2.4 & 1.1 \\
\hline Self-pollination & 0.2 & 1.4 & 1.1 & 0.9 \\
\hline
\end{tabular}

Table 4. - SSR alleles detected in the paternal genotypes.

\begin{tabular}{|l|c|c|c|}
\hline SSR locus & Myrobalan & Moniquí & Moniquí Borde \\
\hline pchgms2 & $130 / 140 / 160 \mathrm{bp}$ & $150 / 160 \mathrm{bp}$ & $150 / 160 \mathrm{bp}$ \\
\hline UDP96-003 & $80 \mathrm{bp}$ & $110 \mathrm{bp}$ & $110 \mathrm{bp}$ \\
\hline UDP96-008 & $120 \mathrm{bp}$ & $130 \mathrm{bp}$ & $130 \mathrm{bp}$ \\
\hline
\end{tabular}

